\title{
contenporaneity
}

\section{Raphael and the Redefinition of Art in Renaissance I taly}

Robert Williams

Christopher J. Nygren

\section{Book Review}

Robert Williams, Raphael and the Redefinition of Art in Renaissance Italy. Cambridge: Cambridge University Press, 2017. 314 pp.; 113 b/w ills. Hardcover $\$ 105.00$ (9781107131507)

\section{About the Author}

Christopher J. Nygren is an assistant professor of European art, 1300-1700 at the University of Pittsburgh. He received his PhD in the History of Art from the Johns Hopkins University in 2011. He has held pre- and post-doctoral fellowships from the Kress Foundation, the Mellon Foundation, the Delmas Foundation, and the American Council of Learned Societies. His book, Titian's Icons: Tradition, Charisma, and Devotion in Renaissance Italy, will be published by Penn State University Press in Spring 2020. 


\section{Raphael and the Redefinition of Art in Renaissance I taly}

\author{
Robert Williams
}

\author{
Christopher J. Nygren
}

In April 2018, the field of Italian Renaissance art history was shocked by news of Robert Williams's untimely death. Williams was a leading figure in the field who spoke with an original voice. He worked intensely at the intersections of critical divides-the chasms between image and text, theory and practice, modernity and its others, to name only a few. Williams had been preparing this book on Raphael for over a decade. In that time, Raphael became the battleground on which most claims about the modernity (or non-modernity) of the Renaissance are contested. Declarations of Raphael's modernity have been made since the sixteenth century. But following the publication of Hans Belting's Likeness and Presence: A History of the Image Before the Era of Art (German edition 1990, English translation, Chicago University Press, 1994), Raphael seems to have been certified as the fulcrum on which pivot the majority of art historical accounts tracing the genealogy of artistic modernity. Raphael is the culminating figure in Alexander Nagel and Christopher Wood's Anachronic Renaissance (Zone, 2010), which presents his Stanza della segnatura as "the break that marks the advent of a 'modern' art" (Anachronic Renaissance, 355). Williams's book may be thought of as a thorough-going response to the claims made by such scholars on behalf of Raphael (although it is worth noting that Anachronic Renaissance is not cited in Williams's study of Raphael). For Williams, the modernity of Raphael's art, such as it is, should not be sought in its secularization (Belting) or as resulting from a crisis of faith in painting's ability to transmit meaning (Nagel and Wood). Rather, his modernity resides in the way that he and his workshop fundamentally reorganized and reoriented the practice of painting. Labor, not crisis, is the key term. Within this context, Williams's book is both monumental and important; it will earn the respect of specialists within the field. It also merits consideration from scholars beyond the field of Renaissance art history.

At the core of Raphael and the Redefinition of Art in Renaissance Italy is a bold claim regarding not only the practice of Renaissance art history, but also how the discipline of art history is subjected to the conditions of modernity. Williams stakes this claim early when he asserts that "modernism has obscured just how modern Raphael was," continuing to note that "our understanding of modernity - that is, of ourselves - is incomplete until we correct this situation" (1). As the book unfolds, it becomes clear that Williams is not using early modern sources simply to reconstruct the details of Raphael's career (indeed, Williams is scrupulous in pointing out where and how the primary sources are inaccurate). Instead, he examines the descriptions of Raphael's contribution in order to reveal how the art world was undergoing fundamental transformations around 1500. The task he set himself is to show how Raphael and his workshop transformed the practice of painting. As Raphael's workshop grew and the master developed a systematic approach to representation that relied on the collective efforts of numerous painters with specialized areas of expertise, intellectual labor and physical labor became enmeshed. From his close reading of primary sources, Williams excavates the reorientation of labor practices as one of the primary elements of note in the early lives of the artist as well as one of the constituent features of Raphael's modernity.

The book develops over three chapters, each dedicated to revising a key concept. The first chapter focuses, in a word, on style. Giorgio Vasari observed that Raphael radically transformed the style of painting: in what did this transformation consist? In offering a critical reassessment of Vasari's claims, Williams makes clear that "style" is not reducible to ductus, or how the painter applies pigment to a surface. Rather, style concerns another key concept: imitation. Williams suggests that Raphael developed a form of critical imitation that allowed the artist to integrate the divergent styles of his contemporaries into a single "synthetic" style that superseded its predecessors. This was, in Williams's account, a monumental achievement in abstract rationality: “Vasari's account suggests that Raphael's achievement was to have created a specifically supra-regional, transnational style, and that its specifically transnational 
or 'universal' quality was part of what was felt to make it modern" (7). In Williams's account, Raphael engaged in a self-conscious recalibration of his style, and the historically informed nature of Raphael's reorientation distinguishes it as a founding moment in modern subjectivity.

Chapter two presents decorum as the framework over which Raphael's systematic approach to representation was constructed. According to Williams, decorum is not a force of constraint but rather a philosophical and rhetorical concept capable of unveiling the essence of things. Williams is aware that this might be a hard sell: "As the heirs to modernism, we have a very hard time conceiving of decorum as anything but a repressive idea. For us [moderns], it is the principle that compels art to follow social norms, to reinforce stereotypes; it is the principle of censorship, the very antithesis of creativity" (9). However, for those steeped in pre-modern rhetorical theory, Williams's reorientation of the term will be familiar: in classical rhetoric, tailoring language to an occasion was not a constraint but rather a spur to thinking in the subjunctive mode-about what might be the case. Decorum forces the consideration of possibilities other than those that exist in the current state of affairs, whether this be in the depiction of historical episodes (how did people dress at the time of Attila's march on Rome?), the suspension of natural laws (what does it look like when God intervenes in the natural world?), or any number of other historical contingencies. Redescribing Raphael's art as an exploration of decorousness (in the rhetorical rather than normative sense) effectively transforms it into an exploration of potentiality rather than actuality. The upshot is that our understanding of Raphael's art is transposed from style in search of "naturalism" (however defined) to something that is probative, examining in different idioms-portraiture, sacred narrative, devotional images, for instance-where expressive potential and truth may be found.

Labor is at the heart of the third chapter, which seeks to understand the development of Raphael's workshop as a response to the changing character of the economy circa 1500. Raphael and his team were subject to market forces not unlike those seen in the contemporary economy: the decreasing power of guilds (unions) resulted in a generalized anxiety for young artists; advances in technology allowed a select few artists to exert quasi-monopolistic power over entire regions, forcing their peers to become more migratory, chasing what little work remained; and patrons became less interested in painting as a product of manual labor and more interested in it as a commodity to be collected. This chapter is exemplary in how it reintegrates narrowly focused studies of economic history into the history and theory of early modern art. More than anywhere else in the book, Williams here reveals his ethical and intellectual commitments with vigor and clarity. Despite his admiration for long, periodic sentences, the prose remains forceful and cutting.

Williams's account of Raphael is stimulating and challenging. Rather than being principally concerned with the rise of naturalism, he believes that the distinctive achievement of the Renaissance rests on the twin ideas of discursivity and decorum. These are complex and abstract notions, the stakes of which are elaborated in a thorough introduction and a brief conclusion. In these chapters, Williams develops his argument through an attentive reading of early modern sources, demonstrating that authors like Vasari, Giovanni Battista Armenini, and Giovanni Paolo Lomazzo (among many others) understood the achievement of Renaissance art to reside in its philosophical engagements. How can painting-an obviously fictive artprobe the depths of truth? If modern thinkers like John Ruskin and Martin Heidegger offer one account that seems, in the first instance, to preclude Renaissance art from engaging with deeper truths because it is predicated on illusionism, Williams reads primary sources against the grain to reveal how Renaissance art probed the depths of philosophical concepts like Truth and Potentiality. This is an ambitious line of argument that many outside the field of Renaissance studies may feel is inflating the period precisely at the moment when its star is finally receding over the horizon. This pushback is welcome. This book is not an exercise in resuscitating the cult of genius that later attached to Raphael and his contemporaries. By the same token, Williams believes that merely decrying the cult of genius is not sufficient. Rather than praise Raphael, this book looks to elucidate how, through his engagement with 
discursivity and decorum, Raphael produced art that has philosophical stakes beyond its aesthetic appeal. These stakes, for Williams, place Raphael firmly on this side of modernity. Through his ingenious mode of argumentation, Williams anticipates the objections of many readers and in doing so reveals yet another illusion of Modernism. He insists that the Renaissance understood art as a mode of inquiry into being-in-the-world; Modernity stakes its own uniqueness on refusing to grant art of earlier periods that mandate. For Williams, such chauvinism must be resisted.

Williams put incredible work into the scholarly apparatus for this volume. The footnotes (rather than endnotes, hallelujah!) are a veritable wellspring of insight. Cambridge University Press should be commended for including original language citations in the footnotes: lengthy passages of Italian, Latin, and German (among others) allow scrupulous readers to confront their reading of the primary sources against Williams's honorable translations. The layout of the pages is handsome and includes illustrations of most of the images discussed in the text. However, all illustrations are in black-and-white. In an era when HD color images are accessible online, this is understandable. But with exclusively B/W illustrations, one would hope to see a lower sticker price ( $\$ 105.00$ !). Regardless, this is an important volume and one that will make Williams's voice heard for generations to come.

(c) $\mathbf{B Y}$ New articles in this journal are licensed under a Creative Commons Attribution 4.0 United States License.

\section{ULLIS D-Surle}

This journal is operated by the University Library System of the University of Pittsburgh as part of its D-Scribe Digital Publishing Program, and is co-sponsored by the University of Pittsburgh Press. 